\title{
PLANT REGENERATION FROM PROTOPLAST OF BRAZILIAN CITRUS CULTIVARS ${ }^{1}$
}

\author{
FERNANDA JANUZZI MENDES DA GLORIA², FRANCISCO DE ASSIS ALVES MOURÃO FILHO², \\ and BEATRIZ MADALENA JANUZZI MENDES ${ }^{4}$
}

\begin{abstract}
A procedure is described to regenerate plants from protoplasts of Brazilian citrus cultivars, after isolation, fusion and culture. Protoplasts were isolated from embryogenic cell suspension cultures and from leaf mesophyll of seedlings germinated in vitro. The enzyme solution for protoplast isolation was composed of mannitol $(0.7 \mathrm{M}), \mathrm{CaCl}_{2}(24.5 \mathrm{mM}), \mathrm{NaH}_{2} \mathrm{PO}_{4}(0.92 \mathrm{mM})$, MES $(6.15 \mathrm{mM})$, cellulase (Onozuka RS - Yakult, 1\%), macerase (Onozuka R10 - Yakult, 1\%) and pectolyase Y-23 (Seishin, $0.2 \%$ ). Protoplast culture in liquid medium after chemical fusion lead to the formation of callus colonies further adapted to solid medium. Somatic embryo formation occurred spontaneously after two subcultures, on modified MT medium supplemented with $500 \mathrm{mg} / \mathrm{L}$ of malt extract. Well defined embryos were germinated in modified MT medium with addition of $\mathrm{GA}_{3}(2.0 \mu \mathrm{M})$ and malt extract $(500 \mathrm{mg} / \mathrm{L})$. Plant regeneration was also achieved by adventitious shoots obtained through direct organogenesis of not well defined embryos in modified MT medium with addition of malt extract $(500 \mathrm{mg} / \mathrm{L}), \mathrm{BAP}(1.32 \mu \mathrm{M}), \mathrm{NAA}(1.07 \mu \mathrm{M})$ and coconut water $(10 \mathrm{~mL} / \mathrm{L})$. Plantlets were transferred to root medium. Rooted plants were transferred to a greenhouse for further adaptation and development.
\end{abstract}

Index terms: cultivar improvement, polyethylene glycol, rootstock, tissue culture.

\section{REGENERAÇÃO DE PLANTAS A PARTIR DE PROTOPLASTOS DE CULTIVARES BRASILEIRAS DE CITROS}

\begin{abstract}
RESUMO - O objetivo deste trabalho foi regenerar plantas a partir de protoplastos de cultivares brasileiras de citros, após isolamento, fusão e cultura. Protoplastos foram isolados a partir de células embriogênicas em suspensão e de mesófilo foliar de plântulas germinadas in vitro. A solução enzimática para o isolamento de protoplastos foi composta de manitol $(0,7 \mathrm{M}), \mathrm{CaCl}_{2}(24,5 \mathrm{mM}), \mathrm{NaH}_{2} \mathrm{PO}_{4}$ (0,92 mM), MES (6,15 mM), celulase (Onozuka RS - Yakult, 1\%), macerase (Onozuka R10 - Yakult, $1 \%$ ) e pectolyase Y-23 (Seishin, $0,2 \%$ ). A cultura dos protoplastos em meio líquido após fusão química levou ao desenvolvimento de microcolônias e calos, posteriormente adaptados para meio semi-sólido. A embriogênese somática ocorreu espontaneamente, após dois subcultivos em meio de cultura MT suplementado com $500 \mathrm{mg} / \mathrm{L}$ de extrato de malte. Embriões bem desenvolvidos germinaram em meio MT modificado, com a adição de $\mathrm{GA}_{3}(2,0 \mu \mathrm{M})$ e extrato de malte $(500 \mathrm{mg} / \mathrm{L})$. A regeneração de plantas também foi obtida por organogênese direta, com a formação de ápices caulinares a partir de embriões menores, em meio MT modificado com a adição de extrato de malte $(500 \mathrm{mg} / \mathrm{L})$, BAP $(1,32 \mu \mathrm{M})$, NAA $(1,07 \mu \mathrm{M})$ e água de coco $(10 \mathrm{~mL} / \mathrm{L})$. As plântulas foram transferidas para meio de enraizamento e, posteriormente, para casa de vegetação, para fins de adaptação e desenvolvimento.
\end{abstract}

Termos para indexação: cultura de tecidos, melhoramento, polietileno glicol, porta-enxerto.

\footnotetext{
${ }^{1}$ Accepted for publication on June 10, 1999.

${ }^{2}$ Agronomist, Dep. de Produção Vegetal, ESALQ-USP, Caixa Postal 09, CEP 13418-900 Piracicaba, SP, Brasil. FAPESP scholarship.

${ }^{3}$ Agronomist, Ph.D., Dep. de Produção Vegetal, ESALQ-USP. CNPq scholarship. E-mail: famourao@carpa.ciagri.usp.br

${ }^{4}$ Agronomist, Dr., Laboratório de Biotecnologia de Plantas, CENA-USP, Caixa Postal 96, CEP 13400-970 Piracicaba, SP, Brasil. CNPq scholarship.
}

\section{INTRODUCTION}

Although there is a great diversity in the genus Citrus, the greatest number of new citrus varieties which are important today originated as bud mutations from existing cultivars (Soost \& Cameron, 1975). The lack of good results through conventional citrus breeding can be explained by various aspects of the biology of the genus Citrus and its relatives, 
including high heterozygozity, pollen and ovule sterility, sexual incompatibility, nucellar polyembryony and juvenility (Vardi et al., 1975; Vardi, 1981; Vardi \& Spiegel-Roy, 1982; Ling et al., 1989; Vardi \& Galun, 1989; Grosser \& Gmitter Junior, 1990).

Somatic hybridization through protoplast fusion allows the combination and hybridization of different sexually incompatible genera and species, which is difficult or impossible by conventional breeding (Vardi \& Galun, 1989; Grosser \& Gmitter Junior, 1990). Protoplasts can be isolated from different kinds of tissues, such as leaf mesophyll, embryogenic callus, embryogenic suspension cultures and non embryogenic callus (Grosser \& Gmitter Junior, 1990).

Protoplasts can readily be fused by either chemical or physical methods (Grosser \& Gmitter Junior, 1990). The chemical method using polyethylene glycol (PEG) has been used extensively at many laboratories, because it has been shown to be simple, efficient, inexpensive, and does not seem to interfere with protoplast viability (Mourão Filho, 1995; Mourão Filho et al., 1996). According to research done so far, citrus protoplasts from one of the parental sources must have a capacity for embryogenesis as a requirement for plant regeneration following protoplast fusion.

Protoplast fusion and citrus somatic hybridization have been an important tool in cultivar development schemes in countries such as USA (Gmitter Junior et al., 1992; Grosser, 1994), Israel (Vardi et al., 1975; Vardi \& Spiegel-Roy, 1982), Japan (Kobayashi \& Ohgawara, 1988; Miranda et al., 1997), and France (Ollitrault \& Luro, 1995).

In Brazil, research on citrus callus induction (Oliveira et al., 1994b) and embryogenic cell suspension cultures (Oliveira et al., 1994a) have been reported, including the successful isolation and culture of protoplasts of several Brazilian varieties (Cristofani, 1991; Oliveira et al., 1995).

This research had the objective to adapt and optimize a protoplast to plant system protocol for Brazilian citrus cultivars.

\section{MATERIAL AND METHODS}

\section{Plant material}

Plant material used for protoplast isolation included embryogenic suspension cultures of Caipira sweet orange (Citrus sinensis L. Osbeck) and leaves of seedlings germinated in vitro of Rangpur lime (Citrus limonia L. Osbeck). Embryogenic calli of Caipira sweet orange were obtained by culturing unfertilized ovules on modified MT medium (Murashigue \& Tucker, 1969) with $500 \mathrm{mg} / \mathrm{L}$ of malt extract (EME). These calli were subcultivated every two weeks in liquid medium (liquid EME), at $100 \mathrm{rpm}$, in the dark, for the production of the embryogenic suspension cultures. Seeds of Rangpur lime were excised from mature fruits and surface sterilized in sodium hypochloride solution (1.5\%), for 15 minutes, and washed in sterile distilled deionized water. The seeds were introduced into Magenta boxes and cultivated in RMAN medium (Grosser \& Gmitter Junior, 1990). Seed germination and initial plant development occurred at $27^{\circ} \mathrm{C}$, with 16 hours of light (5,000 lux).

\section{Protoplast isolation}

The enzyme solution for protoplast isolation was composed of mannitol $(0.7 \mathrm{M}), \mathrm{CaCl}_{2}(24.5 \mathrm{mM}), \mathrm{NaH}_{2} \mathrm{PO}_{4}$ (0.92 mM), MES (6.15 mM), cellulase (Onozuka RS - Yakult, 1\%), macerase (Onozuka R-10 - Yakult, 1\%) and pectolyase Y-23 (Seishin, $0.2 \%$ ). The general protoplast isolation protocol was adapted from Grosser \& Gmitter Junior (1990). Protoplast isolation from embryogenic suspension culture utilized approximately $500 \mathrm{mg}$ of fresh cultured cells (drained) $+2.0 \mathrm{~mL} 0.6 \mathrm{M}$ $\mathrm{BH}_{3}+2.0 \mathrm{~mL}$ enzyme solution. Protoplast isolation from leaf mesophyll was accomplished with $3 \mathrm{~mL}$ of enzyme solution $+1 \mathrm{~g}$ of leaves (feathered or cut into thin strips with a sharp scalpel) $+8 \mathrm{~mL}$ of $0.6 \mathrm{M} \mathrm{BH}_{3}$ (Grosser \& Gmitter Junior, 1990). Protoplast isolation was completed after 14-16 hours of incubation in the dark, at $40 \mathrm{rpm}$.

\section{Protoplast purification}

After incubation, protoplast preparations were purified on a sucrose-mannitol gradient (Grosser \& Gmitter Junior, 1990) as follows: protoplast preparations were first passed through a $50 \mu \mathrm{m}$ nylon mesh screen to remove undigested cell clumps and debris and collected to $15 \mathrm{~mL}$ screw-top centrifuge tubes. Then the material was centrifuged at $100 \mathrm{~g}$ for $4-10$ minutes. The variation in time was based on the volume of material. The supernatant was removed with a Pasteur pipet, and the pellet was gently resuspended in $5 \mathrm{~mL} \mathrm{CPW}$ medium (Frearson et al., 1973) 
containing $25 \%$ sucrose $2 \mathrm{~mL}$ of CPW medium containing $13 \%$ mannitol was slowly pipeted directly on top of the sucrose layer, avoiding any mixing of the two layers. The tubes were centrifuged for six minutes at $100 \mathrm{~g}$. Viable protoplasts were collected in a band at the interface between the two layers. These protoplasts were collected by a Pasteur pipet and resuspended in appropriate amount of $\mathrm{BH}_{3}$ medium (Grosser \& Gmitter Junior, 1990) in another centrifuge tube. Purified protoplasts were then ready for further manipulation.

\section{Protoplast fusion and culture}

Chemical fusion was performed according to Grosser \& Gmitter Junior (1990) and Mourão Filho (1995), with a few adaptations in the protocol as follows. After purification, protoplasts from both parents were diluted at $2 \times 10^{5}$ protoplasts $/ \mathrm{mL}$ and mixed in equal volumes. Two drops of this mixture were placed in the center of a Petri dish $(58 \times 15 \mathrm{~mm})$ for protoplast fusion. Two drops of PEG solution (Mourão Filho, 1995) were added immediately to each Petri dish and incubated for eight minutes. Following this incubation period with PEG solution, two drops of A + B elution solution (9:1 v:v, Grosser \& Gmitter Junior, 1990) were added to each fusion dish at the side of the shallow liquid pool at the center of each dish. After another incubation of 12 minutes, 12 drops of fresh $\mathrm{BH}_{3}$ medium were added around the periphery of the fusing protoplasts. Following another incubation of five minutes, PEG + elution solution were carefully and slowly removed with a Pasteur pipet, and immediately replaced with 15 drops of $\mathrm{BH}_{3}$ medium. After 10 minutes, the medium was carefully removed and replaced with another 12-15 drops of fresh $\mathrm{BH}_{3}$ medium. This step was repeated two more times, with great care to avoid removing protoplasts from the fusion Petri dishes. After the final wash, protoplasts were cultured directly in the fusion Petri dishes by adding the 4-8 drops of protoplast culture medium in a shallow pool in the center of the Petri dish. Several drops of fresh protoplast culture medium were placed around the perimeter to maintain high humidity. Fusion plates were incubated in darkness, at $28^{\circ} \mathrm{C}$. Three different protoplast culture media were selected and used for protoplast culture after fusion. These media were $\mathrm{BH}_{3}(0.7 \mathrm{M})$, EME $(0.7 \mathrm{M})$, and a mixture of $\mathrm{BH}_{3} / \mathrm{EME}$ (1:1 v:v)

Cultures with small colonies were supplemented after 3-5 weeks with liquid medium containing reduced osmoticum. This medium consisted of 10-12 drops of a 1:1:1 (v:v:v) mixture of $\mathrm{BH}_{3}$ medium $(0.6 \mathrm{M})$ :EME medium (0.6 M):EME medium $(0.145 \mathrm{M})$ (Mourão Filho, 1995; Mourão Filho et al., 1996). Following another incubation period of 2-4 weeks, further reduction of osmoticum was accomplished by adding 1-2 $\mathrm{mL}$ of $1: 2$ mixture of $\mathrm{BH}_{3}$ medium $(0.6 \mathrm{M})$ : $\operatorname{EME}(0.145 \mathrm{M})$ per plate. At this point, vigorous cultures were transferred (by pouring) to $100 \mathrm{~mm}$ x $15 \mathrm{~mm}$ Petri dishes containing agar-solidified EME medium. All other liquid culture plates were supplemented with 10-12 drops of liquid 1:2 medium every 2 weeks until adequate growth allowed transfer to solid medium.

\section{Somatic embryogenesis and plant regeneration}

Somatic embryo formation occurred spontaneously, after subcultures of the calli obtained from the protoplast cultures. Well defined embryos were germinated in modified MT medium with addition of $\mathrm{GA}_{3}(2.0 \mu \mathrm{M})$ and malt extract $(500 \mathrm{mg} / \mathrm{L})$. Plant regeneration was also achieved by adventitious shoots obtained through direct organogenesis from abnormal embryos in modified MT medium with addition of $500 \mathrm{mg} / \mathrm{L}$ of malt extract (EME), BAP $(1.32 \mu \mathrm{M})$, NAA $(1.07 \mu \mathrm{M})$, and coconut water $(10 \mathrm{~mL} / \mathrm{L})$. Shoots were transferred to RMAN medium for root formation (Grosser \& Gmitter Junior, 1990). Regenerated rooted plants were finally transferred to commercial potting mixture to a greenhouse for further adaptation and development.

\section{RESULTS AND DISCUSSION}

Figs. 1a and $1 \mathrm{~b}$ show purified protoplasts isolated from embryogenic suspension cultures and leaf mesophyll, respectively. Fig. 1c shows protoplasts after the addition of PEG solution. The arrow points to a fusion between an embryogenic suspension and a leaf mesophyll derived protoplasts. Other nonfused protoplast can also be observed. Initial cell division was observed approximately 10 days after protoplast fusion and plating (Fig. 1d). No major differences were observed on protoplast platting efficiency (defined as the percentage of protoplast that divide to produce callus colonies) as related to the three culture media tested. These observations differ from previous research which indicated that the carbon/osmoticum source (sugar and sugar alcohols) used in various Citrus protoplast media do play an important role on these processes. Previous research had indicated that low cell densities ( $\sim$ × $10^{4}$ protoplasts $\left./ \mathrm{mL}\right)$ and low mannitol concentrations $(\sim 0.4 \mathrm{M})$ induced higher frequency of embryogenesis in sweet orange (Kobayashi et al., 1985). The results of the present work show that plant 


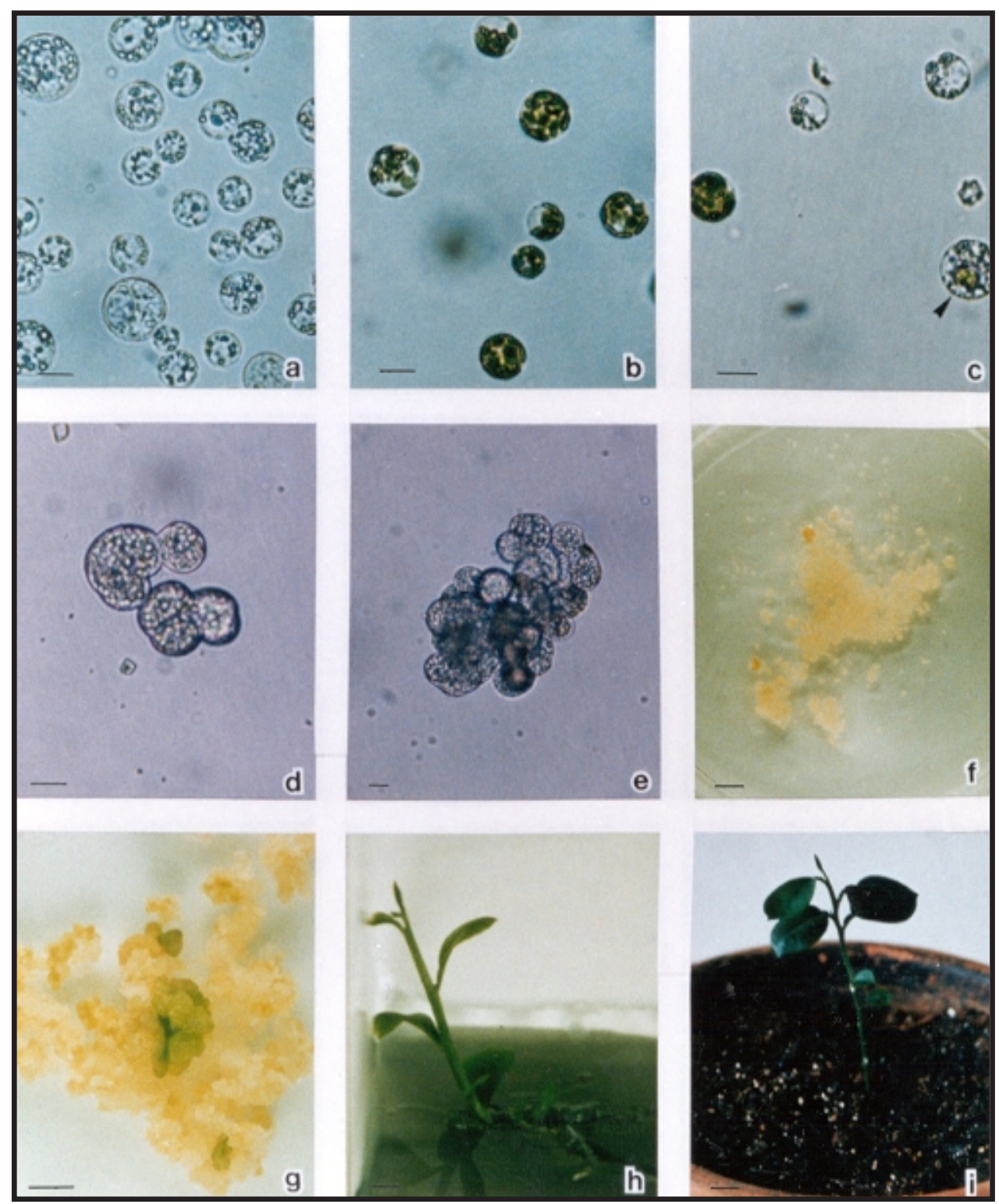

FIG. 1. a. Isolated and purified protoplasts from sweet orange ovule-derived embryogenic callus, in suspension cultures ( $\mathrm{bar}=10 \mu \mathrm{m})$; b. isolated and purified protoplasts from leaf mesophyll of seedlings germinated in vitro $(\mathrm{bar}=10 \mu \mathrm{m})$; c. protoplasts just after the addition of PEG solution. The arrow shows a fusion between an embryogenic suspension and a leaf mesophyll cell derived protoplast $($ bar $=10 \mu \mathrm{m})$; d. initial cell division, approximately 10 days after protoplast fusion and platting (bar $=10 \mu \mathrm{m})$; e. cell cultures with small colonies $(\mathrm{bar}=10 \mu \mathrm{m})$; f. vigorous colonies after transferring to solidified medium (bar $=5 \mathrm{~mm}$ ); g. somatic embryo induction $(\mathrm{bar}=0.5 \mathrm{~cm}) ; \mathrm{h}$. shoots transferred to rooting medium $(\mathrm{bar}=0.5 \mathrm{~cm}) ;$ i. regenerated plant, transferred to commercial potting mixture, in greenhouse $(\mathrm{bar}=2.5 \mathrm{~cm})$. 
regeneration was also possible in higher osmoticum $(\sim 0.7 \mathrm{M})$.

Cultures with small colonies (Fig. 1e) were supplemented after three to five weeks with liquid medium reduced osmoticum. Fig. 1f shows vigorous cultures transferred to agar-solidified EME medium. These colonies adapted to the solid medium environment in two to four weeks. In general, callus cultures showed intermediate vigor. Calli were transferred to new solid EME medium every four to six weeks.

Somatic embryo formation occurred spontaneously, after two subcultures (Fig. 1g). Previous work also showed that EME medium is one of the best composition for somatic embryo formation in sweet orange (Grosser \& Gmitter Junior, 1990; Mourão Filho, 1995), although the addition of other growth regulators and sugars have also proven to be efficient in citrus somatic embryo induction, such as coconut water, galactose and lactose (Kobayashi et al., 1984; Ling et al., 1990). Jumin \& Nito (1996) also demonstrated that the addition of $5 \%$ sucrose and $4.4 \times 10^{-3} \mu \mathrm{M}$ BAP to the MT basal medium induced the highest platting efficient for protoplasts of different citrus relatives.

These embryos continued to be subcultured on solid EME for development. Previous work had determined that increased amounts of malt extract in the medium $(1,500 \mathrm{mg} / \mathrm{L})$ would promote embryo development (Grosser \& Gmitter Junior, 1990; Mourão Filho, 1995), but this proved not to be beneficial in this case. Some small embryos transferred to this media showed callus formation and no development.

After two more subcultures in regular solid EME embryos were transferred to modified MT medium with $\mathrm{GA}_{3}(2.0 \mu \mathrm{M})$ and malt extract $(500 \mathrm{mg} / \mathrm{L})$. In general germination occurred in 5 to 8 weeks after culture. Ling et al. (1990) also observed embryo development of calli originated from protoplasts of Satsuma mandarin in culture medium supplemented with $\mathrm{GA}_{3}$. Grosser \& Gmitter Junior (1990) have also reported embryo germination for several citrus species in MT medium supplemented with $\mathrm{GA}_{3}$.

Shoots were transferred to RMAN medium for root formation (Fig. 1h). Regenerated rooted plants were finally transferred to commercial potting mixture and to a greenhouse for further adaptation and development (Fig. 1i). All regenerated plants were morphologically normal.
Caipira sweet orange and Rangpur lime are very important rootstocks cultivars for the citrus industry in many producing areas in the world, especially in Brazil (Saunt, 1990). Both rootstocks have complementary horticultural characteristics, therefore the production of a somatic hybrid combining these two genotypes could be beneficial and possibly contribute to the development of new citrus rootstocks.

\section{CONCLUSIONS}

1. The protocol developed and adapted in this research is efficient for protoplast isolation, fusion and culture, and plant regeneration of the cultivars studied.

2. The results for the combination Caipira sweet orange + Rangpur lime show that the protocol can be applied in fusion experiments for somatic hybrid production involving other Brazilian cultivars.

\section{ACKNOWLEDGEMENT}

To Fundação de Amparo à Pesquisa do Estado de São Paulo (FAPESP/Brasil), for providing financial support to this research.

\section{REFERENCES}

CRISTOFANI, M. Adaptação de metodologias de cultura de tecidos visando o melhoramento através de indução de mutações em Citrus sinensis (L.) Osbeck cv. Pêra. Piracicaba : USP, 1991. 185p. Dissertação de Mestrado.

FREARSON, E.M.; POWER, J.B.; COCKING, E.C. The isolation, culture, and regeneration of Petunia leaf protoplasts. Developmental Biology, San Diego, v.33, p.130-137, 1973.

GMITTER JUNIOR, F.G.; GROSSER, J.W.; MOORE, G.A. Citrus. In: HAMMERSCHLAG, F.A.; LITZ, R.E. (Eds.). Biotechnology of perennial fruit crops. Wallingford : CAB International, 1992. p.335-369.

GROSSER, J.W. Observations and suggestions for improving somatic hybridization by plant protoplast isolation, fusion, and culture. HortScience, Alexandria, v.29, p.1241-1242, 1994.

Pesq. agropec. bras., Brasília, v.35, n.4, p.727-732, abr. 2000 
GROSSER, J.W.; GMITTER JUNIOR, F.G. Protoplast fusion and citrus improvement. Plant Breeding Reviews, Portland, v.8, p.339-374, 1990.

JUMIN, H.B.; NITO, N. Plant regeneration via somatic embryogenesis from protoplasts of six plant species related to Citrus. Plant Cell Reports, Berlin, v.15, p.332-336, 1996.

KOBAYASHI, S.; IKEDA, I.; NAKATANI, M. Induction of nucellar callus from orange (Citrus sinensis Osb.) ovules, and uniformity of regenerated plants. The Bulletin of the Fruit Tree Research Station: Series E, Akitsu, n.5, p.43-54, 1984.

KOBAYASHI, S.; IKEDA, I.; UCHIMIYA, H. Conditions for high frequency embryogenesis from orange (Citrus sinensis Osb.) protoplasts. Plant Cell, Tissue and Organ Culture, Dordrecht, v.4, p.249-259, 1985.

KOBAYASHI, S.; OHGAWARA, T. Production of somatic hybrid plants through protoplast fusion in citrus. JARQ, v.22, p.181-188, 1988.

LING, J.T.; NITO, N.; IWAMASA, M. Plant regeneration from protoplasts of Calamondin (Citrus madurensis Lour.). Scientia Horticulturae, Amsterdam, v.39, p.325-333, 1989.

LING, J.T.; NITO, N.; IWAMASA, M.; KUNITAKE, H. Plant regeneration from protoplasts isolated from embryogenic callus of Satsuma. HortScience, Alexandria, v.25, n.8, p.970-972, 1990.

MIRANDA, M.; MOTOMURA, T.; IKEDA, F.; OHGAWARA, T.; SAITO, W.; ENDO, T.; OMURA, M.; MORIGUCHI, T. Somatic hybrids obtained by fusion between Poncirus trifoliata $(2 \mathrm{x})$ and Fortunella hindsii (4x) protoplasts. Plant Cell Reports, Berlin, v.16, p.401-405, 1997.

MOURÃO FILHO, F.A.A. Protoplast fusion of Citrus for rootstock and scion improvement with emphasis on wide hybridization. Gainesville : University of Florida, 1995. 152p. Ph.D. Thesis.

MOURÃO FILHO, F.A.A.; GMITTER JUNIOR, F.G.; GROSSER, J.W. New tetraploid breeding parents for triploid citrus cultivar development. Fruit Varieties Journal, University Park, v.50, n.2, p.76-80, 1996.

MURASHIGUE, T.; TUCKER, D.P.H. Growth factor requirements of Citrus tissue culture. In: INTERNATIONAL CITRUS SYMPOSIUM, 1., 1969
Riverside. Proceedings. Riverside : University of California, 1969. p.1155-1161.

OLIVEIRA, R.P. de; MENDES, B.M.J.; TULMANN NETO, A. Cultura de células em suspensão de dois porta-enxertos de citros. Revista Brasileira de Fisiologia Vegetal, Londrina, v.6, n.2, p.141-144, 1994a.

OLIVEIRA, R.P. de; MENDES, B.M.J.; TULMANN NETO, A. Determinação de metodologia para o isolamento de protoplastos de tangerina Cleópatra (Citrus reshni Hort.). Scientia Agricola, Piracicaba, v.52, n.1, p.38-42, 1995.

OLIVEIRA, R.P. de; MENDES, B.M.J.; TULMANN NETO, A. Obtenção e cultura de calos nucelares de limão Cravo, tangerina Cleópatra e Poncirus trifoliata . Revista Brasileira de Fisiologia Vegetal, Londrina, v.6, n.2, p.115-119, 1994b.

OLLITRAULT, P.; LURO, F. Amélioration des agrumes et biotechnologie. Fruits, Paris, v.50, p.267-279, 1995.

SAUNT, J. Citrus varieties of the world. Norwich : Sinclair International, 1990. 126p.

SOOST, R.K.; CAMERON, J.W. Citrus. In: JANICK, J.; MOORE, J.N. (Eds.). Advances in fruit breeding. West Lafayette : Purdue University Press, 1975. p.507-540.

VARDI, A. Protoplast derived from different citrus species and cultivars. International Society of Citriculture Proceedings, Riverside, v.1, p.149-152, 1981.

VARDI, A.; GALUN, E. Isolation and culture of Citrus protoplasts. In: BAJAJ, Y.P.S. (Ed.). Biotechnology in agriculture and foresty: plant protoplasts and engeneering. Berlin : Springer, 1989. v.8, p.147159.

VARDI, A.; SPIEGEL-ROY, P. Plant regeneration from Citrus protoplasts: variability in methodological requirements among cultivars and species. Theoretical and Applied Genetics, Berlin, v.62, p.171-176, 1982.

VARDI, A.; SPIEGEL-ROY, P.; GALUN, E. Citrus cell culture: isolation of protoplasts, platting densities, effect of mutagens and regeneration of embryos. Plant Science Letters, Amsterdam, v.4, p.231-236, 1975. 